\title{
地理学における数理的手法の発達
}

\author{
杉 浦 芳 夫* \\ Progress of Quantitative Methods in Geography
}

Yoshio SUGIURA

I. はじめに

統計学, 数学等の数理的手法を用いて, 地理学固有の理論の構築と, それによる現象説明をめざす地理 学(方法論)が認知されるようになったのは, 斯学が計量革命の洗礼をうけて以後のてとである。地理学に おける理論化・計量化を指向する運動は計量革命とよばれ (BURTON 1963), 1950年代末, アメリカ・ワ シントン大学において最初の烽火をみた。同大学以外にも, 中西部のアイオワ, ノースウェスタン, ウィ スコンシン, シカゴの各大学が革命の中心となり, MICMOG (Michigan Inter-University Community Mathematical Geographers) の結成，イギリスへの革命の伝播という経過をへた後, MICMOG の発展 的解消結果である Geographical Analysis 誌の誕生をもって, 計量革命は欧米の地理学界において受容 されるに至った。

1970年代以降，てうした数理的手法を用いた地理学のいきすぎた計量化に対し批判も提出されているが, それが扱うテーマのいくつかは, 研究内容がより深化し, 隣接学問分野に影響を与え始めているのも事実

第 1 表 アメリカ地理学において用いられている 数理的手法（1954１965年）

\begin{tabular}{lrcrl}
\hline \hline 分析手法 & 博士論文数 $(\%) *$ & 雑誌論文数 $(\%)^{*}$ \\
\hline 共分散分析 & 4 & $(6.0)$ & 4 & $(6.5)$ \\
分散分析 & 5 & $(7.5)$ & 4 & $(6.5)$ \\
カイ二乗検定 & 1 & $(1.5)$ & 2 & $(3.2)$ \\
因子分析・多変量解析 & 5 & $(7.5)$ & 3 & $(4.8)$ \\
最近接尺度・方格法 & 6 & $(9.0)$ & 1 & $(1.6)$ \\
点双列相関分析 & 0 & $(0.0)$ & 1 & $(1.6)$ \\
順位相関分析 & 2 & $(3.0)$ & 1 & $(1.6)$ \\
(重)相関・回帰分析 & 47 & $(70.1)$ & 40 & $(64.5)$ \\
空間統計学的方法 & 4 & $(6.0)$ & 8 & $(12.9)$ \\
確率モデル & 9 & $(13.4)$ & 8 & $(12.9)$ \\
その他** & 8 & $(11.9)$ & 7 & $(11.3)$ \\
\hline
\end{tabular}

* 重複可

**判別分析, グラフ理論, 調和解析, スケイログラム分 析, 空間的相互作用モデル, Probabilities of extremes

出典 : LAVALLE et al. (1967)
である。以下, 本稿では, 対象を人文地 理学に限定した上で, この 4 半世紀の間 に地理学が保有するに至った基本的な数 理的手法について，それが用いられるよ うになった背景に言及しつつ, 概観して みたい。

\section{II. 統計学の信奉}

第 1 表は, 1954年から1965年の間のア メリカ地理学界における博士論文ならび 飞雑誌論文 (Ann. Assoc. Amer. Geogr., Econ. Geogr., Geogr. Rev.) 飞おい て用いられた数理的手法の使用頻度をま とめたものである (LAVALLE et al. 19 67)。表をみる限りでは, 計量革命とは,

（重）相関・回帰分析といった統計学的 手法の地理学への導入であったといって も過言ではない。特に, その傾向が著し かったのが, アイオワ, ウィスコンシン

* 東京都立大学理学部地理学教室 Department of Geography, Tokyo Metropolitan University 
の両学派であった。MCCARTY et al. (1956) の機械製造業の立地分析に代表されるように，当時のとの 種の方法の適用手順怯，1）仮説提出，2）関連変数の選択，3）（重）相関係数・(重) 回㷌式の計算， 4) 適合度検定，5）残差分布の考察，からなっており，まさに統計学の直截的援用であった。誤った統 計学の使用には一定の注意がはらわれ, 統計学は地理学にとって有効な分析方法であるという認識が一般 的であった。ただし，回帰分析を援用した当時の論文が，残差の経験的解釉に熱心であったにもかかわら ず，その際に観察される残差の空間的に系統だった分布，すなわち残差の空間的自己相関の問題について は，その地理学的意義か殆ど認識されていなかった。

後の時期における地理学の展開を考光るとき, 実は, 第 1 表においてウェイトの小さい分析手法, すな わち統計学的方法以外のものが重要であったといえる。それらの多くのものは, ワシントン学派の人々に よって斯学に紹介された。まず, 広義には統計学的方法の範疇に入るものではあるが, 心理学において発 達した多変量解析（主成分分析, 因子分析）が極めて早い時期に導入された。それは, ワシントン学派の BERRY によって積極的に陚みられ，特に，中心地の階層・中心機能の階次区分への二因子型因子分析の 適用（BERRY and BARNUM 1962）は，手法の構造か涀象のそれとうまく合致した成功例であった。そ の後, 因子分析は, クラスター分析とともに，等質地域区分，機能地域区分にも適用され，さらに正準相 関分析と併用されることによって，両地域の対応関係を明らかにしうるまでになった（BERRY 1966）。ま た，因子分析は，その使用が地域区分といった伝統的地理学のテーマに限定されるととなく，都市内部居 住人口の特性分布を研究する因子生態研究, 都市群の根底に横たわる社会・経済・文化・人口学的な基本 的次元を抽出しようとする都市群システム研究等の新たな分野をうみだした。

\section{III. 空間分析の胎動}

しかし, ワシントン学派のこうした方面での貢献は, むしろ, 点, 線, 面といった幾何学的要素によっ て構成される空間システムの解明を可能とする空間分析手法の地理学への導入にあったといえる。てれに よって, SCHAEFER（1953）が標榜した「空間の科学としての地理学」は, 名実ともに第1歩をふみだす ことになった。まず, 点パターンの分析については, 各点にとっての最近接点ないしは $n$ 次の近接点まで の平均距離と, 点の分布がポアソン分布に従う場合に期待される点間平均距離との比から, ‘均等”, “凝集”,

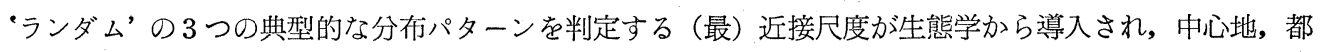
市の空間的分布パターンの定量的把握が可能となった（DACEY 1962）。それ以降，エントロピー測度，2 次元スペクトル分析といったより高度な分析手法も開発されている (HAGGETT et al. 1977)。

また, 線パターンの分析については, グラフ理論に基づくネットワーク分析により, 主として交通網の 構造分析が可能となった。すなわち, 都市をグラフの頂点, 交通路をグラフの辺とみなし, 両者の数を用 いて定義される $\alpha, \beta, \gamma$ 指数等は, 交通網全体の結合度の地域間比較を可能とした (GARRISON and MARBLE 1965)。そして, 都市間の結合関係の有無を 2 值データ表示した $0-1$ 型行列の幕乗演算から求 められる Shimbel 指数等の近接性測度は, 各都市の他都市に対する近づきやすさを定量的に示すととを 可能とした (GARRISON 1960)。2 值データ行列のより精緻化された分析方法としては Q-analysis があ り，それによって現象がもつ多次元空間構造が把握される (GATRELL 1983)。

さらに, 面パターン分析については, 地質学で開発された傾向面分析が導入された (KRUMBEIN and GARRISON 1963)。傾向面分析は，ある分布数值を， $x, y$ 座標によって直交多項式近似するものであり， 全体の分布パターンを, 全域的傾向と局地的成分に区別することを可能とするものである。傾向面分析の 登場により, 同心円パターン, 扇形パターン等の様々な空間的パターンの客観的識別が可能となり, 都市 内人口密度分布や農業生産性分布のように, 当該分布パターンをうみだす理論的根拠を有する分野にとっ ては, 有効な分析方法となった。近年では, 名義尺度で測定されたデータに適用されるロジット傾向面分 析（WRIGLEY 1977）や，時間座標も独立変数の中にくみとんだ 4 変量傾向面分析（ROBINSON and 
SALIH 1974）も開発されている。

\section{IV. 空間的自己相関概念の発見}

統計学を重視する立場と空間分析を重視する立場は, 1970年代に入り, 空間的自己相関のとり扱いをめ ぐり, 初めて接点をもつととになる。空間的自己相関とは, ある地点での分布数值が隣りあう地点での值 と相互に関係しあっているてとをさし示す概念であるが, 推測統計学的方法を適用するに当たっては, 観 察值の相互独立性が仮定されているため, 観察值それ自体あるいは残差に空間的自己相関が存在してはな らない。しかし，皮肉にも，地理学が扱う現象は空間的自己相関にみちみちており，それが学問成立の根 拠ともなっている。早い時期に統計学の分野の空間的自己相関に関連する検定測度をレヴューしたDACEY （1965）の下で修士課程をおえた後，イギリス・ブリストル大学へ進んだ CLIFF は，統計学者 Ord とと もに，各研究者が独自にウェイト係数に創意工夫をとらすととができる，空間的自己相関測度（一般化 Moran 統計量, 一般化 Geary 統計量) の開発に成功した。彼らの研究はまもなく 1 冊の本（CLIFF and ORD 1973）にまとめられるが，そこでは，それまで統計学的方法の適用を妨げるノイズとして否定的に とらえられてきた空間的自己相関概念が，むしろ地理学の理論構築の鍵概念として肯定的に位置づけられ ている。そして, それに呼応する形で, 空間的自己相関の存在を容認しない統計学は, 必ずしも地理学に とって有用なものではないという意見が提出されはじめた（GOULD 1970）。

とてにおいて, 統計学の地理学における“処遇”が問題となるが, それに対しては 4 つの対処方法があ ると考えられる。第 1 は, 記述統計学の立場に立ち, あくまでも現象記述のために統計学を用い, その限 りにおいて, 空間的自己相関の問題は回避しうるとする考え方がある。第 2 は, 空間的自己相関を補正・ 除去した上で, 統計学的手法を適用しようとする考方方がある。しかし，てれは，斯学にとって，貴重な ものを捨てさって，無用なものを残すととになる恐れがあるかもしれない。第 3 は，観察值の相互独立性 の仮定を必要としない分析手法を考案・導入しようとする考穴方がある。Q-analysis や後述の多次元尺 度構成法はとうした考光方沿うものといえる。第 4 は，むしろ空間的自己相関そのものをとりてんだ， より普遍的な空間モデルを構築しようとする考光方がある。

との第 4 の方向てそが，正しく推定された回帰式を用いての地域予測に強い関心を抱くブリストル学派 が追求するものである。1）時系列データを扱う計量経済学の分野において自己相関問題の幾多の研究蓄 積があるとと，2）地域予測という変化を問題にするとと，から，時間的次元をもとりとんだ時・空間的 自己相関が, 彼らの主要な関心となったてとはいうまでもない。その結果, 時間, 空間それ自体を陽表的 に現象生起メカニズムにくみこんだ，時・空間系列モデル族がうまれることになった。その代表は，時点 $t$ 亿おける地点 $i$ での変数の值 $Y_{i t}$ が, その地点と他の地点 $j$ のそれ以前の值 $Y_{i}, t_{t-k}, Y_{j, t-k}$ 亿依存 する生成過程を仮定する, 時・空間自己回帰モデル $Y_{i t}=a \sum_{k=1}^{m} Y_{i},{ }_{t}-{ }_{k}+b \sum_{j=1}^{n} \sum_{k=1}^{m} W_{i} Y_{j}, t_{t}-{ }_{k}+\varepsilon_{i t}$ (ただし， $\mathrm{W}_{i} ;$ は地点 $i, j$ 間の関係を表わすウェイト係数, $a, b$ はパラメータ, $\varepsilon_{i}$ は誤差) であ る。基本モデルとしては, この他に, 時・空間移動平均モデル, 時・空間回帰モデルがあり, これらが相 互にくみあわさったより複雑なモデルも存在する。

以上のモデルは, 疾病の伝播や景気変動の波及 (CLIFF et al. $1975 ； 1981)$ といった 1 変量時・空間系 列を対象とするモデルであるが, 相互に関連しあい, かついずれも自己回帰構造を有する変量間において は, 自らの自己回帰成分のみならず，互いの変量をモデル式中にとりてんだ形の多変量時・空間系列モデ

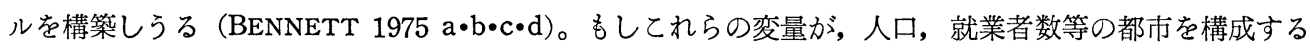
要素であれば, 一群のモデル式は, まさにシステムとしての都市を表現しているものに他ならない。した がって, ある時点における変量值を, 推定されたモデル式の入力データとするととによって, 将来の都市 システムの状態を予測するてとは不可能ではない。かくして, システムズ分析と空間分析が統合された多 変量時・空間系列モデルは，健全な地域管理を行なうための指針を与えるととに貢献するのである。 


\section{V・地図を歪める試み}

空間的自己相関測度や時・空間系列モデルに登場する, 地点間の関係を示すウェイトは, 地図上で計測 された距離を用いて定義されるととが多い。空間論的にみると, そてに愓所の位置関係を絶対的なも のとみなす絶対空間の概念が含意されている (HARVEY 1969)。物理学における現代の主要な空間概念は 相対空間の概念であるが，地理的空間を物理空間と同一視し，てうした空間概念の変化に従うべきか否か は意見のわかれるところである。とりあえずは，空間分析も空間論と整合性をもった形でなされるべきで あるととを指摘しておきたい。

とはいえ，現代地理学では，活動や対象それ自体が影響場としての空間（の幾何学）を決定するとの認 識の下に，距離のメトリックを相対視する傾向にある。通常の地図上では無秩序状態を呈する現象であっ ても, 地理的変異自体を修正し, 密度が一様な分布に変換するととができるならば，隠された秩序をみい だしうるであろう（TOBLER 1963）。密度変換とは座標の変換を意味するてとに他ならないのであり，座 標空間が次元数と距離の測定方法によって定義されるととを考光ると，ててにおいて密度変換と距離メ卜 リックの変換との関連が暗示される。かかる方面での先駆的実証研究としては, カルトグラムにより, 需 要密度を一様にして理論的な商店立地を考察した GETIS（1963）の研究がある。そして, 近年，てうし た要請に応じる形で心理学から導入されたものが, 点間距離の関係からその背後にある空間の復元を可能 とする多次元尺度構成法 MDS である（GATRELL 1983）。乙れによって，入力データとして，地点間の 時間距離や認知距離を用意すれば，時空間（第 1 図），個人の認知空間が復元されるのである。

a ）現実の地図

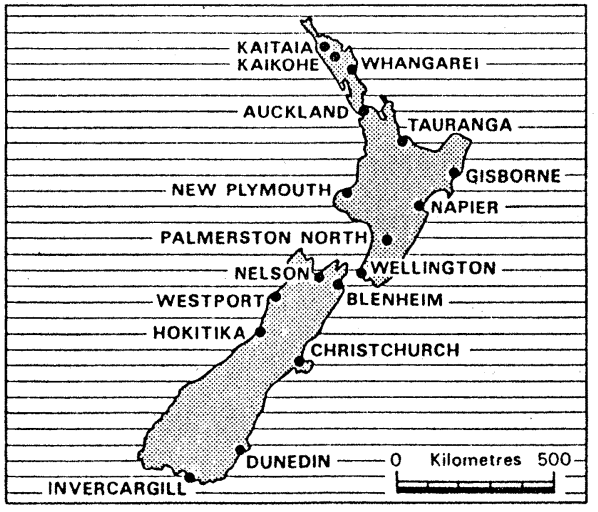

b) 時空間

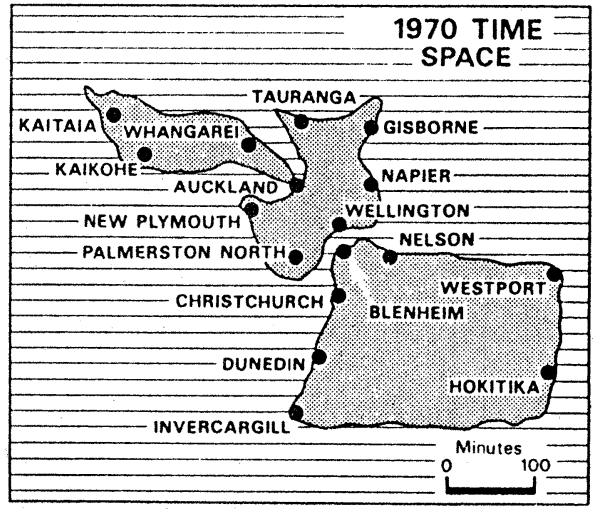

第1図 ニュージーランドの時空間

出典 : GATRELL（1983）

\section{VI. 空間的相互作用モデルの復活}

空間構成要素である距離を陽表的に現象説明に用いたモデルとしては，重力モデルがある。重力モデル は，計量革命にひとつのインパクトを与えた分野である社会物理学（BURTON 1963）を中心にして，以 前から, 物資, 人口, 情報等の地点間流動現象の解析に用いられてきた。万有引力の法則とのアナロジー で成立する重力モデルは, 次式のように, 地点 $i, j$ 間の流動量 $I_{i} ;$ が, 両地点の人口 $P_{i}, P_{j}$ の積に比

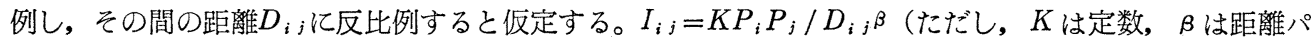
ラメータ)。重力モデルの流動現象への適合度は常に良好であったが，その理論的根拠は乏しかった。

こうした情況において，WILSON（1970）は，最も実現性の高い流動パターンとは，総数 $N$ 個の移動を， 
$n \times n$ 種類の地点の組合せに配分する場合の数の最大值に他ならないとし, 重力モデルの再定式化を図っ た。最も実現性の高い流動パターンを記述する式が，統計力学的エントロピーないしは情報エントロピー に近似した形を示すてとから，彼はてれをエントロピーとなづけ，それを最大化するととによって，次の ようなエントロピー最大化型空間的相互作用モデルを誘導した。 $I_{i j}=A_{i} B_{j} O_{i} D_{j} \exp \left(\beta D_{i j}\right)($ ただし， $A_{i}, B_{j}$ は制約条件をみたすために導入された均衡因子, $O_{i}$ は地点 $i$ の総流出量, $D_{j}$ は地点 $j$ の総流入 量）。乙のモデル式は, 通常の重力モデルに総流出量と総流入量の制約を加えた発生・吸収制約型重力モ デルと構造上は同一であり，ててにおいて，エントロピー概念によって重力モデルの理論的根拠が与えら れたととになった。なお, エントロピー最大化型空間的相互作用モデル族は, 都市内部の人口, 小売・サ 一ビス活動の分布を記述・予測する Lowry モデルのモデル構成要素をなしていた人口（市場）ポテンシ ヤルに代わって用いられるととにより, Lowryモデルと合体して, 都市モデリングの分野を新たに形成し た（BATTY 1976）。

ととろで,一般に, 重力モデルの距離パラメータは, 空間的相互作用に及ぼす距離の影響を示すものと 考えられていたが，人口分布に空間的自己相関がみられると，モデル式中の分子にも距離の要素が混入 し, 距離パラメータは距離効果を正確に表現しえないととになる。また, この結果, 最小二乗法によって 求められる距離パラメータは偏りをもつととになる。人口の空間的自己相関の有無は, 各地点の位置関係 に依存するため, 距離パラメータは, 発地点と着地点の組合せからなる地図パターンの影響をうける可能 性がある。地図パターンの距離パラメータへの影響に関する論争は, 1970年代中葉, Regional Studies 誌 上で展開されたが, いまもって結論はでていない。ての論争は, 最小二乗法によってパラメータ推定を行 なう重力モデルを用いてなされたが，エントロピー最大化型空間的相互作用モデルが地図パターン問題を 克服しうるか否かは不明である。

\section{VII. 行動論の登場}

社会物理学とともに, 計量革命にインパクトを与えた学問分野としては, ISARD が主宰した地域科学 があった。経済学が「一点世界」からの脱却を図るととによってうまれた空間経済学としての地域科学が, 研究の対象を共有する立地論とともに, 立論に際し用いた大前提は, 人間の経済的合理性に基づく最適化 行動である。この結果うまれる経済活動の最適立地パターンを考察するとき, 制約条件を一次不等式で表 現し, 目的関数の最大化・最小化を図ることによって最適解を求める線形計画法は, 地理学にとって有用 な分析手法となった。線形計画法は, ワシントン学派経由で地域科学から斯学へ最も早く導入された数理 的手法であるといっても過言ではない。医療施設利用行動を空間的価格均衡問題としてとらえ, 最適な空 間的利用パターンを線形計画法で示した MORRILL（1959）の研究は，その代表である。以後，線形計画 法は, 主に移動・輸送費用最小化の仮定の下で, 最適な施設利用圈の画定問題, 最適な施設配置問題, 両 者を同時にとり扱う立地・配分問題へと，その応用範囲を拡大していった（KILLEN 1983）。

しかし，てうした「経済人」とは異なる，現実の人間は，必要な情報を完全に保有するととはなく，し ばしばきまぐれな行動をとる。そこで, 経済人が生きる立地論の世界と, 現実の世界との乘離をうめるべ く登場したのが, 行動科学の枠組みに則った行動論であった。不確定な自然環境下での農民の作物選択問 題をゲーム理論によってとらえる陚み（GOULD 1963），人間の意志決定にみられるランダム性を考慮し た, モンテカルロ法を用いてのイノベーションの空間的拡散モデル（HÄGERSTRAND 1953）は，その先 駆である。

こころで, 経济人概念やそれに代わる満足人概念 (WOLPERT 1964) で語られる人問像は, 依然, 人間 をステレオタイプ化してとらえている。やがて，1960年代後半の行動論に関する初めてのシンポジウムを 境にして,「なまみの人間」の行動が本格的に扱われることになる。その特徽は, 認知, 選好, 態度形成 等の心理的構成概念と心理学の分析手法を用いて，人間の空間的行動を説明しようとするところにある。 


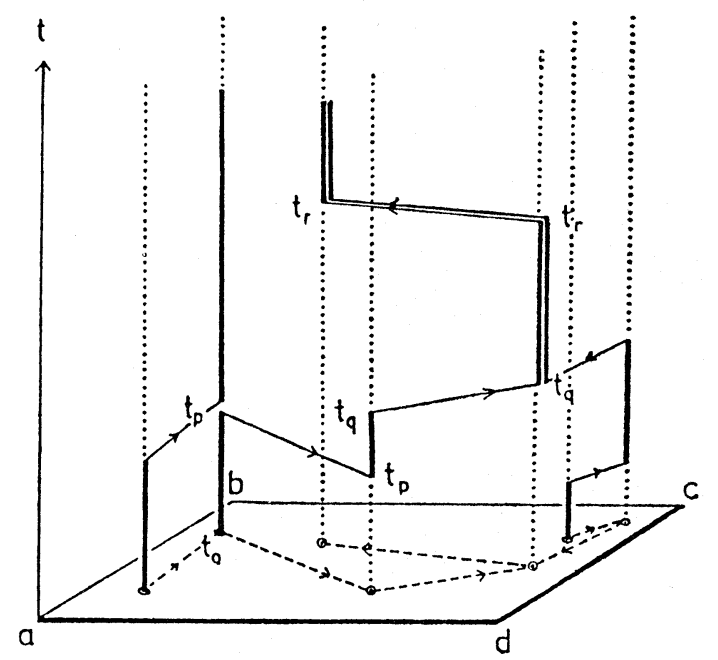

第 2 図 人間の行動の軌跡の 3 次元時・空間表現 出典：HÄGERSTRAND (1963)

MDS を用いての買物行動を規定する選好 構造の抽出 (RUSHTON 1969) や認知空間 の復元 (GOLLEDGE 1978) の他, 主題(絵 画) 統覚テスト, Semantic Differential 法, Repertory Grid 法等を用いての自然 環境の把握，環境イメージの測定は，その 例である。行動論は心理学への傾斜をます ます強めているが (GOLLEDGE and RAYNER 1982)，個人の選択行為とそれが集 計されて観察される全体の選択行動との間 の対応関係を探る目的で経済学において開 発されたロジット分析の導入も, との方面 における近年の目新しい傾向である（WRIGLEY 1979)。

こうした心理的構成概念依扰した行動 論の 1 つの欠点は, 個々の行動を離散的に とらえやすいととである。それに対し，人 間の行動を時・空間座標上において連続的にとら光，時間と空間の制約に注目し，そのモデル化を図る陚 みもある (LENNTORP 1976)。乙れがスウェーデン・ルント大学の Hägerstrand が提唱した Time Geography である (第2 図)。Time Geography は未だ十分体系化されていないが，環境可能論の現代的展 開といえるかもしれない。

\section{VIII. むすび}

学問において，新たな思考の枠組や分析手法がうまれるのには，それなりの背景がある。てれは地理学 の場合も例外ではない。かかる観点の下に, 本稿では, 主に人文地理学における数理的手法の発達に関し 概観した。その過程が, 独自の分析手法の開発というよりも，隣接学問分野からの数理的手法の導入であ ったととは否定できない。とうした“輸入超過”傾向は, 将来も続くことが予想されるが, 考古学におけ る空間分析手法の使用（HODDER and ORTON 1976）俍証されるように，それが多少是正されつつあ るととも最後詣摘しておきたい。

\section{参考文献}

BAtTy, M. (1976) : Urban Modelling. Cambridge University Press, Cambridge, 381 p.

BENNETT, R. J, (1975a) : Dynamic systems modelling of the North-west region : 1. Spatio-temporal representation and identification. Environ. and Plan. A, 7, 525-538.

- (1975b) : Dynamic systems modelling of the North-west region : 2. Estimation of the spatio-temporal policy model. Environ. and Plan. A, 7, 539-566.

- (1975c) : Dynamic systems modelling of the North-west region : 3. Adaptive-parameter policy model. Environ. and Plan. A, 7, 617-636.

- (1975d) : Dynamic systems modelling of the North-west region : 4. Adaptive spatio-temporal forecasts. Environ. and Plan. A, 7, 887-898.

BERRY, B. J. L. (1966) : Essays on Commodity Flows and the Spatial Structure of the Indian Economy. Research Paper, No. 111, Department of Geography, University of Chicago, 334 p.

- and BARNuM, H. G. (1962) : Aggregate relations and elemental component of central place systems. Jour. of Regional Science, 4, 35-68. 
BURTon, I. (1963) : The quantitative revolution and theoretical geography. Canadian Geogr., 7, 151-162. バートン著，野間三郎訳（1976）：計量革命と理論地理学．野間三郎訳編：『空間の理論 の地理科学のフロンティアー』古今書院, 50-68.

ClifF, A. D. and ORD, J. K. (1973) : Spatial Autocorrelation. Pion, London, 178 p.

-, HAGGetT, P., ORD, J. K., BASSETT, K. A. and DAVIES, R. B. (1975) : Elements of Spatial Structure. Cambridge University Press, Cambridge, 258 p.

and Versey, G. R. (1981): Spatial Diffusion: An Historical Geography of Epidemics in an Island Community. Cambridge University Press, Cambridge, $238 \mathrm{p}$.

DACEY, M.F. (1962): Analysis of central place and point patterns by a nearest neighbor method. NORBORG, K. ed.: Proceedings of the IGU Symposium in Urban Geography, Lund 1960. Lund Studies in Geography, Ser. B, No. 24, 55-75.

(1965): A Review on Measures of Contiguity for Two and K-Color Maps. Technical Report, No. 2, Spatial Diffusion Study, Department of Geography, Northwestern University. Reprinted in BERRY, B. J. L. and MARBLE, D. F. eds. : Spatial Analysis : A Reader in Statistical Geography. Prentice-Hall, Englewood Cliffs, N. J., 479-495.

GARRISON, W. L. (1960) : Connectivity of the interstate highway system. Papers and Proceedings of the Regional Science Association, 6, 121-137.

- and MARBLE, D. F. (1965): Prolegomenon to the Forecasting of Transportation Development. Research Report, Transportation Center, Northwestern University, 40-68, 89-96. Reprinted in HURST, M.E.E. ed.: Transportation Geography. McGraw-Hill, New York, 58-80.

Gatrell, A. (1983): Distance and Space. Clarendon Press, Oxford, 195 p.

GETIS, A. (1963): The determination of the location of retail activities with the use of a map transformation. Econ. Geogr., 29, 14-22.

Gould, P.R. (1963) : Man against his environment: a game theoretic framework. Ann. Assoc. Amer. Geogr., 53, 290-297. グールド著，小林 茂訳(1983)：環境と人間一ゲーム理論による考察一. 寺阪炤信編：『理論地理学ノ一ト'82』空間の理論研究会, 17-24.

(1970): Is "statistix inferens" the geographical name for a wild goose ? Econ. Geogr., 46, 439-448.

GOLlEDGE, R. G. (1978) : Learning about urban environments. CARLSTEIN, T., PARKES, D. and THRIFT, N. eds. : Timing Space and Spacing Time Vol. 1 : Making Sence of Time. Edward Arnold, London, 76-98.

— and RAyner, J. N. (1982) : Proximity and Preference. University of Minnesota Press, Minneapolis, $310 \mathrm{p}$.

HÄGERSTRAND, T. (1953) : Innovationsförloppet ur Korologisk Synpunkt. CWK Gleerup, Lund (Pred, A. R. post. and trans. (1967) : Innovation Diffusion as a Spatial Process. The University of Chicago Press, Chicago, 334 p.).

HÄGERSTRAND, T. (1963) : Geographic measurements of migration: Swedish data. SUTTER, J. ed. : Human Displacements : Measurement Methodological Aspects. Hachette, Monaco, 61-83.

HAGGeTt, P., ClifF, A. D. and FREY, A. (1977) : Locational Analysis in Human Geography (Second Edition). Edward Arnold, London, 605 p.

HARVEY, D. (1969) : Explanation in Geography. Edward Arnold, London, 521 p. ハーヴェイ著, 松本正美訳 (1979)：『地理学基礎論』古今書院, 352ページ.

HODDER, I. and ORTON, C. (1976) : Spatial Analysis in Archaeology. Cambridge University Press, Cambridge, $270 \mathrm{p}$.

KILLEN, J. (1983) : Mathematical Programming Methods for Geographers and Planners. Croom Helm, London, 363p.

KRUMBEIN, W. C. and GARRISON, W. L. (1963) : Computer Applications in the Earth and Environmental Sciences : Reports and Computer Manuals. Office of Naval Research, Geography Branch (筆者未見).

LAVAlle, P., McCoNNELl, H. and BROWN, R. G. (1967) : Certain aspects of the expansion of 
quantitative methodology in American geography. Ann. Assoc. Amer. Geogr., 57, 423-436.

LENNTORP, B. (1976) : Paths in Space-Time Environments. Lund Studies in Geography, Ser. B, No. 44,150 p.

McCARTy, H. H., Hook, J.C. and KNOS, D.S. (1956): The Measurement of Association in Industrial Geography. Report 1, Department of Geography, State University of Iowa, $143 \mathrm{p}$.

MORRILL, R, L. (1959) : Models of physician utilization in service areas : measurements of benefits. Garrison, W. L., Berry, B. J. L., MARble, D. F., Nystuen, J. D. and Morrill, R. L. : Studies of Highway Development and Geographic Change. University of Washington Press, Seattle, 257-276.

ROBINSON, G. and SALIH, K. B. (1974) : An illustration of four-variable trend analysis applied to regional growth. Regional Studies, 8, 47-55.

RUSHTON, G. (1969) : The scaling of locational preferences. Cox, K. R. and GolledGE, R. G. eds. : Behavioral Problems in Geography : A Symposium. Studies in Geography, No. 17, Department of Geography, Northwestern University, 197-227.

SCHAEFER, F. K. (1953) : Exceptionalism in geography: a methodological examination. Ann. Assoc. Amer. Geogr., 43，226-249. シェーファー著, 野間三郎訳 (1976)：地理学々おける例外 主義：その方法論的吟味. 野間三郎訳編：『空間の理論一地理科学のフロンティアー』古今書院, $14-47$.

TOBLER, W.R. (1963) : Geographic area and map projections. Geogr. Rev., 53, 59-78.

WiLson, A. G. (1970) : Entropy in Urban and Regional Modelling. Pion, London, 166 p.

WOLPERT, J. (1964): The decision process in spatial context. Ann. Assoc. Amer. Geogr., 54, 537-558. ウォルパート著, 米田 嚴訳 $(1979 \mathrm{a} ・ \mathrm{~b})$ ：Homo economicus「経済人」と経済空間一J. ウォルパート「空間的次元における決定過程」を中心に一（中・下）一. 地理科学，31，41-52； $32,39-43$.

Wrigley, N. (1977): Probability Surface Mapping: An Introduction with Examples and Fortran Programs. CATMOG No. 16, Geo Abstracts, Norwich, 78 p.

(1979) : Developments in the statistical analysis of categorical data. Progress in Human Geography, 3, 315-355. 